\title{
Present Water Crises in Iraq and Its Human and Environmental Implications
}

\author{
Nadhir Al-Ansari', Nasrat Adamo² \\ ${ }^{1}$ Geotechnical Engineering, Lulea University of Technology, Lulea, Sweden \\ ${ }^{2}$ Consultant Engineer, Norrköping, Sweden \\ Email: nadhir.alansari@ltu.se
}

How to cite this paper: Al-Ansari, N. and Adamo, N. (2018) Present Water Crises in Iraq and Its Human and Environmental Implications. Engineering, 10, 305-319. https://doi.org/10.4236/eng.2018.106021

Received: May 21, 2018

Accepted: June 4, 2018

Published: June 7, 2018

Copyright (c) 2018 by authors and Scientific Research Publishing Inc. This work is licensed under the Creative Commons Attribution International License (CC BY 4.0).

http://creativecommons.org/licenses/by/4.0/

\begin{abstract}
Iraq is facing a serious water shortage problem now, which has not been experienced before. This is because of the reduction of flow of the Euphrates and Tigris Rivers which is due to the implementation of hydrological projects within the upstream part of the catchment and climate change. Mismanagement of water resources within Iraq made the problem graver. It is believed that serious discussion with all riparian countries to reach an agreement to share the water of the two rivers and their tributaries is desperately needed. In addition, a prudent scientific strategy should be implemented and put into practice to overcome this problem in Iraq. In addition, the key positions within the Iraqi Ministry of Water Resources should be given to people having real experience in the water resources sector to ensure discreet and prudent management of the problem.
\end{abstract}

\section{Keywords}

Euphrates, Tigris, Climate Change, Water Shortage, Iraq

\section{Introduction}

The Middle East is considered as an arid to semi-arid region where average annual rainfall does not exceed $166 \mathrm{~mm}$ [1] [2]. A good percentage of the agricultural land is rain fed while irrigated agriculture accounts for about $66 \%$ of the water demand [3]. Future prospects of the region indicate that water shortage problem will be more serious [4] [5] [6]. For this reason, fresh potable water is essential for life, socioeconomic development, and political stability in the region [7].

Iraq is located in the Northeastern part of the Middle East (Figure 1). The area of Iraq is $437,072 \mathrm{~km}^{2}$ and the population is 39.3 million [8]. Tigris and 


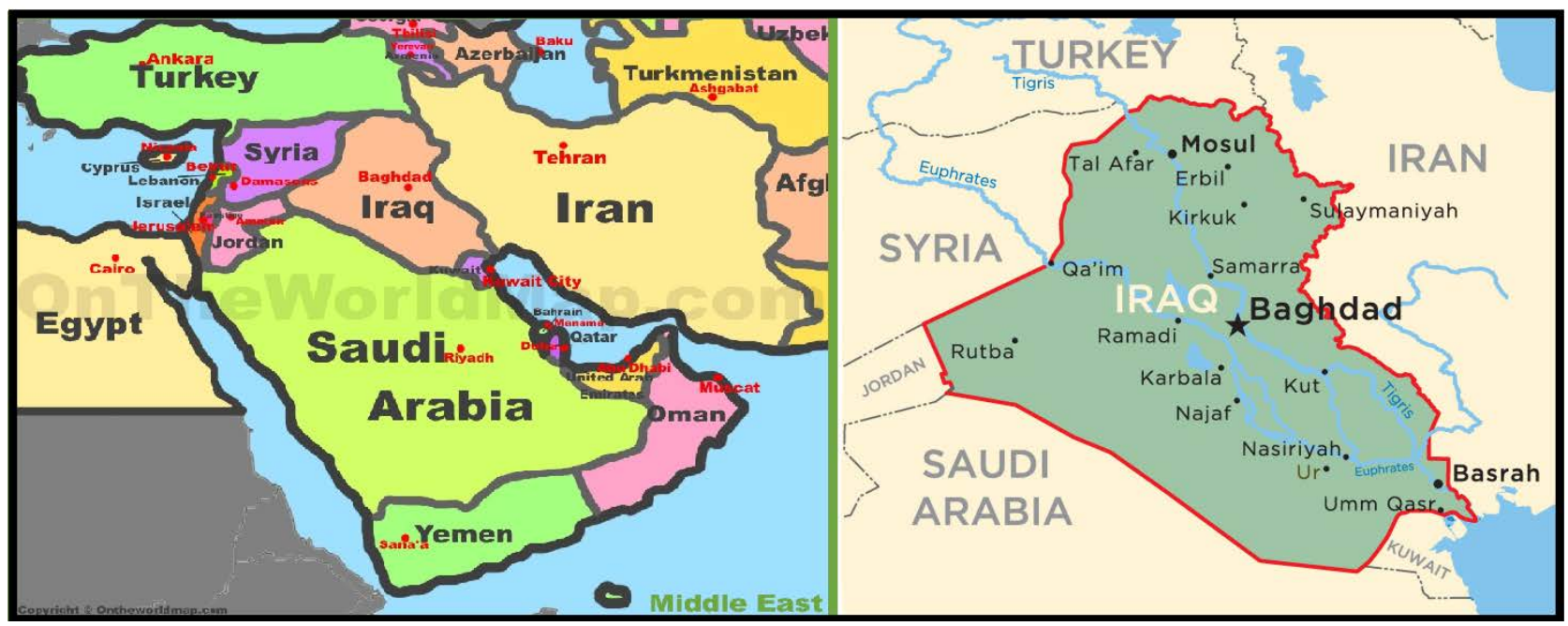

Figure 1. Location of Iraq within the Middle East.

Euphrates are the main two rivers of Iraq. The waters of these rivers come from Turkey (71\%), Iran (6.9\%) and Syria (4\%) while the remainder is from Iraq. This implies that $100 \%$ of the Euphrates and $67 \%$ of the Tigris, waters come from outside Iraq respectively [9] [10]. Groundwater Resources reach 1.2 Billion cubic meters $(\mathrm{BCM})$ and form only $2 \%$ of the consumed water. The flow of the rivers fluctuates from 10 to $40 \mathrm{BCM}$ depending on the hydrological conditions with an average of $30 \mathrm{BCM}$ [10].

Iraq was considered rich with water resources due to the presence of the Tigris and Euphrates Rivers till the 1970s. After that Turkey, Syria and Iran started to implement hydrological projects on the two rivers and their tributaries which affected the flow in these rivers. In addition, the quality of the water deteriorated due to irrigation back waters from upstream projects [11] [12] [13] [14] [15]. In this work, the problems that are affecting the flow and its implication on the population and environment of Iraq are discussed.

\section{Euphrates and Tigris Rivers}

\subsection{River Euphrates}

The river rises from the southeastern parts of Turkey. It is $2781 \mathrm{~km}$ long and is considered as the longest river in southwest Asia. Its catchment area is 444,000 $\mathrm{km}^{2}$ of which $28 \%$ in Turkey, $17.1 \%$ is in Syria and the remainder $39.9 \%$ is in Iraq [12]. About $89 \%$ of the water of the river comes from Turkey [16]. Its flow at Hit city after it enters Iraq has an annual average of 30.6 BCM measured in the period 1938-1973 which had decreased to 22.8 BCM for the period 1974-1998 [16]. The flow now is 18 BCM per year [17] [18].

\subsection{River Tigris}

Tigris River like the Euphrates rises from the southeastern parts of Turkey. It is $1718 \mathrm{~km}$ long, which makes it the second longest river in southwest Asia. It 
drains an area of $472,606 \mathrm{~km}^{2}$ of which lies $17 \%, 2 \%, 29 \%$ and $52 \%$ in Turkey, Syria, Iran and Iraq respectively [13]. The flow of the Tigris River is considered natural until 1973 when dams were started to be built on the river and its tributaries [16]. The average annual discharge for the period 1931-1973 was 21.3 BCM and it decreased to 19.6 BCM for the period 1974-2005 [16] [18]. The discharge of the river at Baghdad was 1207 cubic meters per second (cumecs) for the period 1931-1960. It decreased to 927 cumecs for the period 1961-200 and it is 522 cumecs after the year 2000 [16] [19]. The decrease of flow is caused by building of dams on the main river and its tributaries.

\section{The Water Crises}

The ongoing water crises are the worst that Iraq has experienced. A thorough scan of the crises shows that it can be attributed to two main reasons that can be summarized as follow:

\subsection{External Reasons}

\subsubsection{Water Requirements in Riparian Countries}

The main riparian countries on the Euphrates River catchment are Turkey, Syria and Iraq while on the Tigris catchment they are Turkey, Iran and Iraq. Each riparian country claims their required needs from these rivers, but when these claimed needs are added together, the required amount exceeds the flow of the river. Turkey and Syria claims that it requires 15.7 and $11 \mathrm{~km}^{3}$ respectively of the Euphrates water to irrigate their land while $S$ Iraq require and $13 \mathrm{~km}^{3}$. To put these claims into implementation all the upstream countries started to build dams on the Tigris and Euphrates to ensure getting its claimed quantity of water for its needs because of the high fluctuation of the flow of the rivers. Accordingly, a large number of dams were built (Table 1). Turkey through its Greater Anatolia Project (GAP), which includes 22 dams (14 on the Euphrates) and 8 on the Tigris and 19 hydropower stations [20], has built most of these dams. Iran on its part has built number of dams on the tributaries of the Tigris River [17]. This includes building dams on Alwind, Karkha and Karun Rivers where all the water of these rivers were diverted inside Iran. In addition, most of the valleys on the eastern border with Iraq were diverted inside Iran. The flow of Shat Alarab has been reduced by $41 \%$ and salinity increased to $2408 \mathrm{mg} / \mathrm{l}$ in 2011 [16].

When the GAP project is completed, then $80 \%$ of the Euphrates water will be controlled by Turkey and when Ilisu dam is finished, $47 \%$ of the flow of the Tigris River will be drawn off [24] [25] [26] [27]. About $21 \mathrm{BCM}$ of water used to be received by Syria from the Euphrates before 1990 while it is receiving 12 BCM now. Iraq used to receive $29 \mathrm{BCM}$ which has dropped to $4.4 \mathrm{BCM}$ now. This implies $40 \%$ and $85 \%$ reduction in the quantity of water which Syria and Iraq were receiving respectively [28]. This has caused a reduction of the agricultural land from 650,000 ha to 240,000 ha. Irrigation backwater caused deterioration of the quality of the Euphrates water also. 
Table 1. Dams on Tigris, Euphrates rivers and tributaries (source [21] [22] [23]).

\begin{tabular}{|c|c|c|c|c|}
\hline Dam & River & $\begin{array}{l}\text { Heigh } \\
\mathrm{t}(\mathrm{m})\end{array}$ & Purpose & $\begin{array}{l}\text { Completion } \\
\text { Date }\end{array}$ \\
\hline \multicolumn{5}{|c|}{ IRAN } \\
\hline Dez & Shatt Al-Arab/Karun & 203 & $\mathrm{I} / \mathrm{P}$ & 1963 \\
\hline $\begin{array}{l}\text { Shahid Abbaspour } \\
\text { (Karun 1) }\end{array}$ & Shatt Al-Arab/Karun & 200 & $\mathrm{P}$ & 1976 \\
\hline $\begin{array}{l}\text { Masjed Sulaayman } \\
\text { (Karun 2) }\end{array}$ & Shatt Al-Arab/Karun & 164 & $\mathrm{P}$ & 1976 \\
\hline Karun 3 & Shatt Al-Arab/Karun & 205 & $\mathrm{I} / \mathrm{P} / \mathrm{F}$ & 2002 \\
\hline Karun 4 & Shatt Al-Arab/Karun & 230 & $\mathrm{I} / \mathrm{P} / \mathrm{F}$ & 2010 \\
\hline Garan & Tigris/Diyala/Sirwan & 62 & I & 2005 \\
\hline Darayan & Tigris/Diyala/Sirwan & 169 & $\mathrm{I} / \mathrm{P}$ & 2010 \\
\hline UpperGotvand & Shatt Al-Arab/Karun & 180 & $\mathrm{P}$ & 2012 \\
\hline Lowe Gotvand & Shatt Al-Arab/Karun & 22 & $\mathrm{P}$ & 1977 \\
\hline Karkha & Shatt Al-Arab/Karkha & 127 & $\mathrm{I} / \mathrm{P}$ & 2001 \\
\hline Seimare & Shatt Al-Arab/Karkha & 180 & $\mathrm{P}$ & 2013 \\
\hline Khersan 3 & Shatt Al-Arab/Karun/Karkha & 195 & $\mathrm{P} / \mathrm{F}$ & 2015 \\
\hline \multicolumn{5}{|c|}{ Turkey } \\
\hline $\begin{array}{l}\text { Çetin Dam } \\
\text { (Alkumru) }\end{array}$ & Tigris/Botan & 145 & $\mathrm{P}$ & 2016 \\
\hline Aslanda $\bar{g}$ & Tigris/GreaterZab/Bembo & 60 & $\begin{array}{l}\mathrm{I} / \mathrm{M} / \mathrm{P} \\
\text { (future) }\end{array}$ & 2012 \\
\hline Beyyurdu & Tigris/GreaterZab/Bembo & 48 & $\begin{array}{l}\mathrm{I} / \mathrm{M} / \mathrm{P} \\
\text { (future) }\end{array}$ & $\begin{array}{c}\text { Under } \\
\text { Construction }\end{array}$ \\
\hline Atatürk (Karababa) & Euphrates & 169 & $\mathrm{P}$ & 1992 \\
\hline Balli & Tigris/Khabour/Hezil/Ortasu & 49 & $\mathrm{I} / \mathrm{M} / \mathrm{P}$ & $\begin{array}{c}\text { Under } \\
\text { Construction }\end{array}$ \\
\hline Batman & Tigris/Batman & 74 & $\mathrm{I} / \mathrm{P}$ & 1999 \\
\hline Beyhan I & Euphrates/Murat & 97 & $\mathrm{P}$ & 2015 \\
\hline Beyhan II & Euphrates/Murat & 62 & $\mathrm{P}$ & Planned \\
\hline Birecik & Euphrates & 62.5 & $\mathrm{I} / \mathrm{P}$ & 2001 \\
\hline BurḉBendi & Euphrates/Gö̈ksu & 47 & $\mathrm{P}$ & 2010 \\
\hline Cizre & Tigris/Botan & 46 & $\mathrm{I} / \mathrm{P}$ & Planned \\
\hline Ḉoukurca & Tigris/GreaterZab/Güzedlere & 45.5 & $\mathrm{~W} / \mathrm{M}$ & $\begin{array}{c}\text { Under } \\
\text { Construction }\end{array}$ \\
\hline Dumluka & Euphrates/Bugur & 30 & I & 1991 \\
\hline Erkenek & Euphrates/Adiyaman & - & $\mathrm{p}$ & Operational \\
\hline Gö̈ksu & Euphrates/Gö̈ksu & 52 & I & 1991 \\
\hline Hecihider & Euphrates/Sehir & 42 & I & 1989 \\
\hline Hancaḡiz & Euphrates/- & - & I & 1988 \\
\hline Ilisu & Tigris & 135 & $\mathrm{I} / \mathrm{P} / \mathrm{F}$ & 2017 \\
\hline Upperkalekö̈y & Euphrates/Murat & 137.5 & $\mathrm{P}$ & 2017 \\
\hline
\end{tabular}




\section{Continued}

\begin{tabular}{|c|c|c|c|c|}
\hline Lowerkalekö̈y & Euphrates/Murat & 115 & $\mathrm{P}$ & Planned \\
\hline Karakaya & Euphrates & 158 & $\mathrm{P}$ & 1987 \\
\hline Karkamiṣ & Euphrates & 21.1 & $\mathrm{P}$ & 2000 \\
\hline Kavsaktepe & Tigris/Khabour/Hezil/Ortasu & 66 & $\mathrm{~W} / \mathrm{M}$ & $\begin{array}{c}\text { Under } \\
\text { Construction }\end{array}$ \\
\hline Kayacik & Euphrates/Sajur & 45 & $\mathrm{I} / \mathrm{P}$ & 2005 \\
\hline Keban & Euphrates & 207 & $\mathrm{P}$ & 1974 \\
\hline Kirazlik & Euphrates/Botan & 60 & $\mathrm{I} / \mathrm{P}$ & 2011 \\
\hline Kralkizi & Tigris/Maden & 113 & $\mathrm{I} / \mathrm{P}$ & 1997 \\
\hline Musatatepe & Tigris/Khabour/Hezil/Ortasu & 34.5 & $\mathrm{~W} / \mathrm{M}$ & $\begin{array}{c}\text { Under } \\
\text { Construction }\end{array}$ \\
\hline Silope & Tigris/Khabour/Hezil & 79.5 & $\mathrm{~W} / \mathrm{M} / \mathrm{P}$ & 2012 \\
\hline Silvan & Tigris/Batman & 174.5 & $\mathrm{I} / \mathrm{P}$ & 2017 \\
\hline Sirrntiș & Tigris/Birimşe & 92 & I & 2013 \\
\hline Șirnak & Tigris/Khabour/Hezil/Ortasu & 56.8 & $\mathrm{~W} / \mathrm{M}$ & 2012 \\
\hline Uludere & Tigris/Khabour/Hezil/Ortasu & 55.5 & $\mathrm{~W} / \mathrm{M}$ & $\begin{array}{c}\text { Under } \\
\text { Construction }\end{array}$ \\
\hline \multicolumn{5}{|c|}{ Syria } \\
\hline Baath & Euphrates & 14 & $\mathrm{P}, \mathrm{I}, \mathrm{F}$ & 1988 \\
\hline Tabaqa & Euphrates & 60 & $\mathrm{P}, \mathrm{I}$ & 1975 \\
\hline Tishrine & Euphrates & 40 & $\mathrm{P}$ & 1999 \\
\hline Upper Khabour & Khabour & & I & 1992 \\
\hline
\end{tabular}

F: Flood Control; I: Irrigation; M: Military; P: Power; W: Water supply.

\subsubsection{Climate Change}

Data of climate records indicates that the Middle East and North Africa (MENA) is among the most vulnerable regions of the world to the potential impacts of climate change where increase of temperature is relatively high [29] [30]. This implies that there will be increase of the average temperatures, less and more erratic precipitation, higher transpiration and sea level rise (SLR). Drought will affect the agricultural life and water supply at Middle East [31] due to the fact, that most of the agricultural areas of MENA region are rain-fed [32].

Analysis of the rainfall and temperature records in different parts of Iraq indicates that there will be continues decrease of rainfall and increase in temperature in future [33] [34] [35] [36] [37]. The rainfall will take place in shorter periods and will be more intensive. This will cause high rate of sediment transport leading to decrease of the storage capacity of the reservoirs and low agricultural yield. In addition, the quantity of water infiltration will be decreased and consequently there will be depletion of groundwater resources. Dust storms are expected to increase. 


\subsection{Internal Reasons}

It is very unfortunate that the political system, which was adopted in Iraq since 2003 onwards, depends on sharing power and filling key positions within the different ministries and government departments by the ruling political blocks and parties. Consequently, most of the ministers and director generals that held and are holding positions in the Iraqi ministry of water resources and other ministries using water are not competent, unexperienced and corrupt persons. This has resulted in a very grave situation as far as the water management of water resources of the country is concerned.

The situation concerning water resources can be summarized as follow:

- Supply and Demand: There is a gap between supply and demand [1] [10] [38] [39]. The overall water demand for Iraq ranges between 75 to $81 \mathrm{BCM}$ of which irrigation requirement ranges from 22 to $39 \mathrm{BCM}$ [10]. Real Irrigation efficiency ranges between $25 \%$ to $30 \%$ [10]. The overall agricultural land is about 3.5 million ha, and only about $50 \%$ is cultivated in recent years. If the whole area is cultivated the water required assuming good irrigation efficiency will be $50 \mathrm{BCM}$.

As far as the sanitation sector is concerned water losses are high and the infrastructure of the system is not working efficiently [40]. In any case, the demand for sanitation is $5 \mathrm{BCM}$. Additionally, the hydropower sector (including evaporation from reservoirs) and restoring the marshes requires 10 and $16 \mathrm{BCM}$ respectively. The available water does not exceed 75 BCM [41] [42]. Assuming the situation remains as it is now, then water supply will drop [38] and the demand will be 66.85 BCM [43] or 77 BCM [44].

- Potable Water Distribution Network: About 33\% of the people in Iraq do not have access to safe water and sanitation [1] [45]. Water distribution services have deteriorated and only $73 \%$ and $40 \%-45 \%$ of the people in urban and rural areas are serviced respectively. More information indicates that $79 \%$ of the population has access to drinking water $(92 \%$ in urban and $57 \%$ in rural areas) [46]. This indicates that $21 \%$ have no access to drinking water, and $16 \%$ have daily problems while $7 \%$ have weekly problems, $15 \%$ have less than weekly problems and only $41 \%$ have a reliable source [46]. The estimated water shortage in the domestic sector is $1.7 \mathrm{BCM}$ [45]. The efficiency of the domestic distribution network is $32 \%$ and still deteriorating with time [10] and the demand reaches 11 MCM per day [45].

As far as water treatment is concerned, only $8 \%$ of the population is served in 14 cities out of 252 cities [10]. In view of this situation, most of the sewage water is directly discharged to the rivers without any treatment and the treatment plants require replacement, rehabilitation and upgrading [10]. The domestic and sewage water networks are damaged which causes mixing of drinking water with swage causing infections to the people [10] [46] [47] [48] [49].

- Water Quality: Upstream projects on the Euphrates and Tigris Rivers caused return irrigation flow water quality to deteriorate [15]. It is expected that 
more deterioration will take place due to future implementation of irrigation projects in upstream countries [15] and continuous discharge of sewage and industrial affluent (about 500,000 cubic meters) in the rivers [47]. For these reasons the water quality in both rivers are deteriorating downstream where TDS values reach about $2000 \mathrm{mg} / \mathrm{l}$ in Basra [15] which does not meet the WHO standards [43]. This has caused large number of people to suffer from different diseases particularly due to the leakage of both drinking water distribution and sewerage systems causing high contamination [41] [46] [48] [49]. Due to salinity increase, $4 \%, 50 \%$ and $20 \%$ of the land are severely, medium and slightly saline [50].

- Desertification: The continuous decrease in the flow and increase of salinity of the rivers had caused about $45 \%$ of the area of Iraq to be affected by desertification [51]. According to IAU [43], 20,000 farmers and fishermen left their farms and $40 \%$ of the agricultural cropped areas reduced. In addition, large number of trees was destroyed during both Gulf wars. All these factors increased the desert areas and caused very frequent dust storms.

- Water Resources Mismanagement: Prior to 2003, the ministry responsible for the water resources in Iraq was referred to as the "Ministry of Irrigation". After that, the name of the ministry was changed to be the "Ministry of Water Resources". The political system in Iraq after 2003 is based on sectarian and political quotas. For this reason most of the water resources ministers and director generals within this ministry since 2003 onward are not specialized and unexperienced in the field of water resources. This made the problem of water scarcity graver. Examples of mismanagement in the past couple of years can be summarized as follow:

1) Absence of water use planning or rational strategy for reservoirs operation and water management. For this reason, the reservoirs now are almost empty.

2) Iraq is known for its salinity problems since the dawn of civilization [51]. Due to water logging and salinity, 50\% of the land was degraded in the 1970 s. For this reason, the Ministry of Irrigation launched great efforts to restore the agricultural lands to its previous fertility through implementing drainage systems. The Ministry of Water Resources has neglected its duty to maintain and upkeep of all these projects, which had coasted hundreds of millions dollars, and left them without any real maintenance or rehabilitation and as a result, only $15 \%$ of the drainage system is in operation now.

3) Drowning shallow areas with water like very shallow areas of the marshes. This increased the evaporation and consequently salinization of these lands.

4) The irrigation projects are designed so that certain lands are to be irrigated and the amount of water is calculated according to the agricultural requirements. The ministry diverted the canals to private lands against all the regulations just to satisfy some persons with political influence or for unknown reasons.

5) An Italian company called TREVI was contracted for about 350 million US 
Dollars to do mainly grouting operations in Mosul Dam for 18 months. This contract was renewed for another year for about 100 million US Dollars. Iraqi local staff carried out these operations since 1986. If we consider the cost in case the Iraqi staff will handle the grouting operations, we can save at least $70 \%$ of the 450 Million US Dollars. Other contracts have been awarded even without informing the public. Reasons for such actions if not satisfactorily explained can only be taken as acts of corruption to which all the responsible persons must be brought to accounting. Similarly, all other violations which have been committed in running the water management sector during these years must be investigated and all responsible people should be brought to justice. A firm and tough policy towards corruption must be instated. Transparency in the actions of the Ministry of water resources sector should be respected and upheld.

\section{Discussion}

The Euphrates and Tigris basin are shared by four main countries. These are Turkey, Iran, Syria and Iraq. Iraq being the lowest downstream country is the most effected country by any projects on these rivers and their tributaries in the upstream countries. These countries do not have any agreement about water quotas and or a comprehensive plan for the future management of the catchments of these rivers [14] [28]. Because all these individual countries claim that they have water shortage problems so water is over exploited [41] [52] [53] [54]. This has caused certain conflict between these countries like the tension between Iraq and Syria in 1975 and in the friction between Turkey and Syria in the 1980s [55]. Since Turkey is the riparian hegemon, then there should be some intensive efforts to bring Turkey to the table of negotiations and discussion. The help of an international partner that have the political, technical and financial power to convince all parties [14] [19] can do this. Reaching a solution is vital because the low flow and climate change has led to an abnormal rise of temperatures in Iraq and Syria as well as enhancing dust storms [56] [57] [58] [59] which have very negative consequences on humans and the environment (see Figure 2 and Figure 3).

While trying to reach an agreement with riparian countries, Iraq should take quick measures to construct a prudent and scientific strategy to overcome the water shortage problems. The Iraqi Ministry of Water Resources claims to have a long-term strategy. In this context, no one has seen this strategy or its implementation. Even if such strategy exits, the results are negative indicating that this strategy does not work and should be changed. Al-Ansari [14] [19] [40] suggested a long-term strategy that can be put in practice to overcome this nightmare. This strategy can be summarized as follow:

1) Strategic Water Management Vision: In this context, an integrated water master plan is required. The plan is to be put by individuals that have expertise in water resources at the ministries of Water Resources and Agriculture. Experienced university staff are to participate as well as NGO's. It will be a good idea 


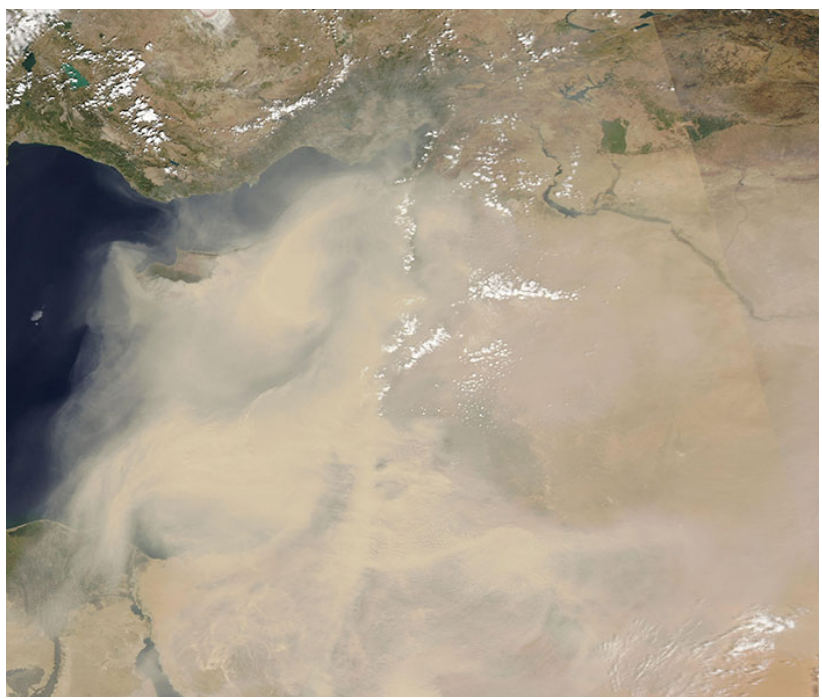

Figure 2. The extent of the dust storm on 8 September 2015 as seen from the Moderate Resolution Imaging Spectroradiometer (MODIS) satellite. Image accessed from NASA Worldview: worldview.earthdata.nasa.gov. (Source [57]).

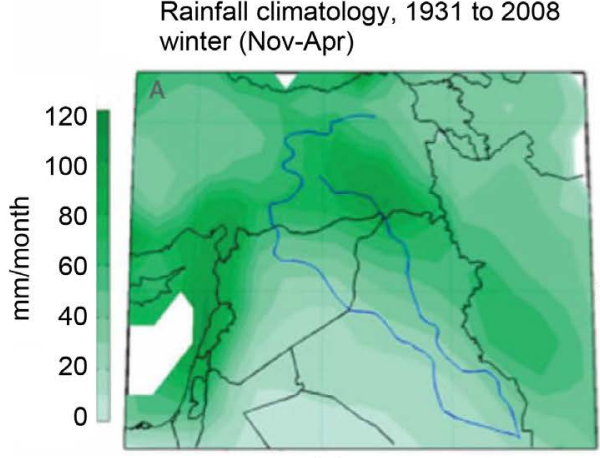

(a)

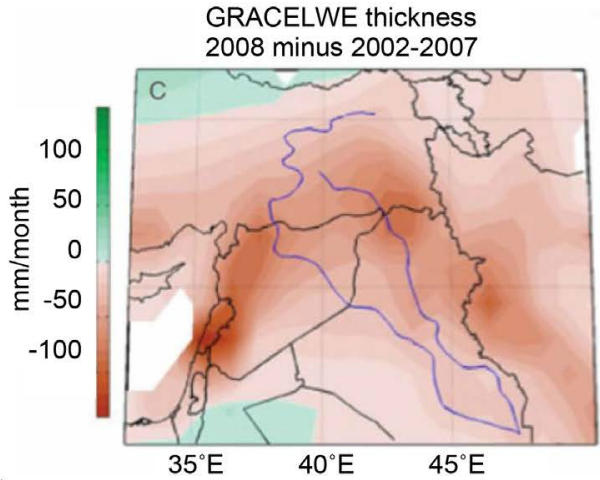

(c)

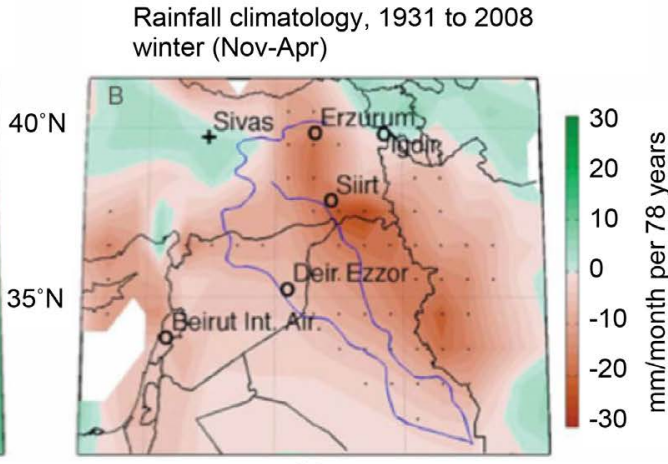

(b)

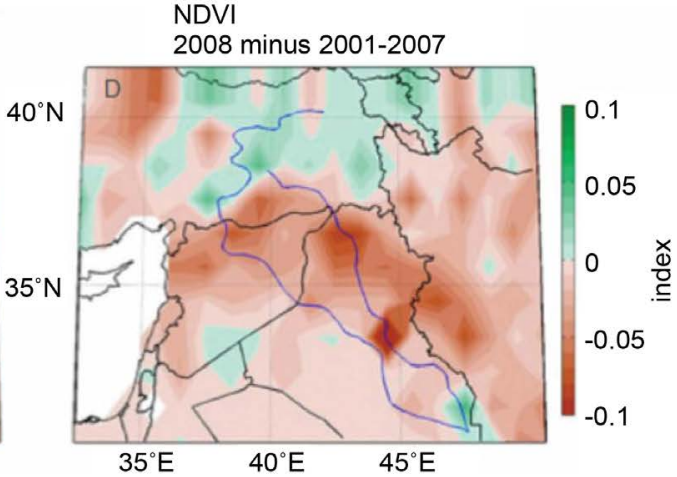

(d)

Figure 3. The Fertile Crescent has been steadily drying since 1931, and recent changes have exacerbated the trend. Map (a) shows winter precipitation from 1931 to 2008. Map (b) shows winter rainfall change from 1931 to 2008 . Map (c) shows a steep decline in groundwater between 2008 and the mean of the previous six years using data from the Gravity Recovery and Climate Experiment (GRACE) satellites. Map (d) shows a decline in vegetation between 2008 and the mean of the previous seven years using Normalized Difference Vegetation Index data from the Moderate Resolution Imaging Spectroradiometer (MODIS) satellite instrument. (Source [58]). 
to include representatives of regional and International organizations concerned. The plan should include the following:

- Rehabilitation of infrastructure, which should cover dams, barrages, weirs as well as pumping stations.

- Improving the efficiency of distribution networks specially diversion and supply down to the point of use.

- Irrigation modernization using suitable techniques. Present methods should be very restricted and new less water consuming techniques should be adopted e.g. drip irrigation.

- Public awareness program is vital so that all the people appreciate the serious problem they are facing.

- Defining institutional agenda including employment and training.

- Supply and demand should be considered. In this context, new non-conventional water resources (water harvesting, treated wastewater) should be considered and evaluated.

- Private sector is to be enhanced to be involved (especially for infrastructural investment).

- The extent of restoring the marshes should be considered in view of water availability.

- Review and amend all the legislations and laws governing the water sector and water use to exercise better control of water sharing between all users and to ensure the proper use of water which should be treated as a rare commodity and stop all types of waste or misuse. The government must also enforce the application of these laws by using its proper instruments to solve individual and tribal conflicts over water issues in the light of the stipulation of these laws.

- A new policy towards water pricing should be introduced to stop water misuse and waste by introducing proper tariff based on the real economic value of water on one hand and to hinder this misuse and waste. Collection method should be based on actual used quantities and away from any type of corruption or manipulation.

- Inter-ministerial coordination is very important. This will save time, effort and money. More decentralization including budget in irrigation, water supply and sanitation sectors are to be practiced.

2) Regional cooperation and coordination: Before starting any discussion with any organization, the institutional and technical needs for cooperation should be defined. Iraq should concentrate its efforts on trans-boundary resources. This can be achieved by discussions with all riparian countries with the help of a mediator that has good political, technical and financial capabilities. Iraq from its side can give incentives to upstream countries so that they will seriously be involved. In addition, UN organizations, International institutions and well known universities can be approached for scientific and technical cooperation.

3) Irrigation and Agriculture: In this sector, plenty of efforts are required. As a 
start, farmers should be trained to use modern irrigation techniques before implementing these techniques. In addition, institutions should reflect decentralization, autonomy and farmer empowerment. Other measures should include:

- Modernizing the irrigation and drainage system.

- Enhancing the private investment in the agricultural sector.

- Using suitable techniques in irrigation (drip irrigation and sprinkler irrigation) and closed irrigation systems.

- Maintenance of irrigation and drainage projects.

- Partially built dams should be completed and starting to build new dams.

- Water harvesting techniques are to be used.

4) Water Supply and Sanitation: Distribution and collection networks are in very bad conditions. This necessitates quick maintenance and restoring distribution and collection networks and services are to be improved.

5) Research and Development: A data bank should be established that includes all reliable data required (climatological, hydrological, geological, environmental and soil) to be used by researchers and decision makers in water resources and agricultural research. Researchers and postgraduate students are to be allowed to have access to the data. The research should highlight the needs and suitability of new techniques in water resources and agriculture to the environment in Iraq. An institute can be established to perform these tasks as well as:

- Establishing training programs for technicians, engineers and decision makers about up to date technologies.

- Executing research to import new technologies in water resources and agriculture which suites Iraq environment.

- Projects, which help in augmenting water resources, developing land productivity, minimizing water use and consumption should be, carried out.

- Setting the outlines of public awareness programs both for water use and agricultural activities.

- Giving advice to universities and institutes to set special courses in arid region hydrology.

6) A thorough examination should be made to all of the organization structures in the water sector to ensure efficiency of work and quick response to arising problems as the present structures proves to be flabby, over staffed and inactive.

\section{Conclusion}

Building of dams and implementation of irrigation projects in the upper parts of the catchment as well as the effect of climate change have caused reduction of the flow of the Euphrates and Tigris Rivers and their tributaries. For these reasons, Iraq is facing a serious water shortage problem now and in the future. The Iraqi Ministry of Water resources mismanagement made the problem even worse. On the regional level it is believed that overcoming the problem requires discussions and negotiations with all riparian countries. This task is very hard to 
achieve and requires a mediator that has political, financial and technical capabilities that can convince all parties. Iraq on its part as being the lowermost country within the Euphrates and Tigris catchment should give some incentives to Turkey so that it considers the problem seriously. This requires also that the Iraqi government in general and the Ministry in particular should take this matter as an existential threat affecting the livelihood of the People of Iraq and act accordingly. Both the government and the Ministry have not done so far enough in this respect and they both need to put more work and effort on this. At the same time, on the local level Iraq the Ministry should put a prudent and scientific strategy for the management of its water resources and apply it correctly. All influences affecting the fair water distribution must be stopped, whether political, tribal or otherwise, and corruption in all its forms must be eradicated starting from the top down to the bottom.

\section{References}

[1] Al-Ansari, N.A. and Knutsson, S. (2011) Toward Prudent Management of Water Resources in Iraq. Journal of Advanced Science and Engineering Research, 1, 53-67.

[2] Roger, R. and Lydon, P., Eds. Water in the Arab Word: Perspectives and Prognoses. Harvard University, Cambridge, MA.

[3] Hiniker, M. (1999) Sustainable Solutions to Water Conflicts in the Jordan Valley. Cambridge Review of International Affairs, 12, 255-273. https://doi.org/10.1080/09557579908400261

[4] Voss, K.A., Famiglietti, J.S., Lo, M.H., Linage, C., Rodell, M. and Swenson, S. (2013) Groundwater Depletion in the Middle East from GRACE with Implications for Transboundary Water Management in the Tigris-Euphrates-Western Iran Region, Water Resources Research, 49, 904-914. https://doi.org/10.1002/wrcr.20078

[5] Chenoweth, J., Hadjinicolaou, P., Bruggeman, A., Lelieveld, J., Levin, Z., Lange, M.A., Xoplaki, E. and Hadjikakou, M. (2011) Impact of Climate Change on the Water Resources of the Eastern Mediterranean and Middle East Region: Modeled 21st Century Changes and Implications. Water Resources Research, 47, 1-18. https://doi.org/10.1029/2010WR010269

[6] Bazzaz, F. (1993) Global Climatic Changes and Its Consequences for Water Availability in the Arab World. In: Roger, R. and Lydon, P., Eds., Water in the Arab Word: Perspectives and Prognoses, Harvard University, Cambridge, MA, 243-252.

[7] Al-Ansari, N.A., Alibrahiem, N., Alsaman, M. and Knutsson, S. (2014a) Water Demand Management in Jordan. Engineering, 6, 19-26. https://doi.org/10.4236/eng.2014.61004

[8] Worldmeters (2018) Iraq Population. http://www.worldometers.info/world-population/iraq-population/

[9] Worldmeters (2018) Turkey Population. http://www.worldometers.info/world-population/turkey-population/

[10] World Bank (2006) Iraq: Country Water Resources, Assistance Strategy: Addressing Major Threats to People's Livelihoods. Report No. 36297-IQ, 97 p.

[11] Kamel, A.H., Sulaiman, S.O. and Mustaffa, S. (2013) Study of the Effects of Water Level Depression in Euphrates River on the Water Quality. Journal of Civil Engineering and Architecture, 7, 238-247. 
[12] Al-Ansari, N., Adamo, N., Sissakian, V., Knutsson, S. and Laue, J. (2018) Water Resources of the Euphrates River Catchment. Journal of Earth Sciences and Geotechnical Engineering, 8, 1-20.

[13] Al-Ansari, N., Adamo, N., Sissakian, V., Knutsson, S. and Laue, J. (2018) Water Resources of the Tigris River Catchment. Journal of Earth Sciences and Geotechnical Engineering, 8, 21-42.

[14] Al-Ansari, N., Adamo, N., Sissakian, V., Knutsson, S. and Laue, J. (2018) Geopolitics of the Tigris and Euphrates Basins. Journal of Earth Sciences and Geotechnical Engineering, 8, 187-222.

[15] Al-Ansari, N., AlJawad, S., Adamo, N., Sissakian, V., Laue, J. and Knutsson, S. (2018) Water Quality within the Tigris and Euphrates Catchments. Journal of Earth Sciences and Geotechnical Engineering, 8, 95-121.

[16] ESCWA (Economic and Social Commission for Western Asia) (2013) Inventory of Shared Water Resources in Western Asia. Salim Dabbous Printing Co., Beirut, 626 p.

[17] Addullah, A.A. (2012) Shared Rivers between Iraq and Iran and Its Effect on Agricultural Lands and Food Security. Tikrit University Journal, 20, 356-388.

[18] Abd-El-Mooty, M., Kansoh, R. and Abdulhadi, A. (2016) Challenges of Water Resources in Iraq. Hydrology Current Research, 7, 1-8. https://doi.org/10.4172/2157-7587.1000260

[19] Al-Ansari, N.A. (2016) Hydropolitics of the Tigris and Euphrates Basins. Engineering, 8, 140-172.

[20] Ali, A.H. (2018) Water Crisis in Iraq: Challenges and Solutions. Al-Bayan Center for Planning and Studies, Baghdad.

[21] Wikipedia (2017) List of Dams and Reservoirs in Turkey/Southeastern Anatolia. https://en.wikipedia.org/wiki/List_of_dams_and_reservoirs_in_Turkey

[22] Wikipedia (2017) List of Dams and Reservoirs in Syria. https://en.wikipedia.org/wiki/Category:Dams_in_Syria

[23] Wikipedia (2017) List of Dams and Reservoirs in Iran. https://en.wikipedia.org/wiki/List_of_dams_and_reservoirs_in_Iran

[24] Beaumont, P. (1996) Agricultural and Environmental Changes in the Upper Euphrates Catchment of Turkey and Syria and Their Political and Economic Implications. Applied Geography, 16, 137-157. https://doi.org/10.1016/0143-6228(95)00033-X

[25] Alyaseri, S. (2009) GAP Project: Dangerous Consequences on Life in Iraq. Official Site of Iraqi Council for Peace and Unity. http://www.ipb.org/members/iraqi-council-for-peace-and-solidarity/

[26] Robertson, C. (2009) Iraq Suffers as the Euphrates River Dwindles. The New York Times.

http://topics.nytimes.com/topics/reference/timestopics/people/r/campbell_robertso $\underline{\text { n/index.html?inline }=\text { nyt-per }}$

[27] Alalaf, I. (2009) Ilisu Dam and Its Effect on Man and Environment in Iraq and Turkey, Batnaya. http://www.batnaya.net/forum/showthread.php?s=9bd97aa8bfae0b9b35554d8ce6c2 787e\&p=151263\#post151263

[28] Al-Ansari, N. (1998) Water Resources in the Arab Countries: Problems and Possible Solutions. UNESCO International Conference on World Water Resources at the Beginning of the 21 st Century, Paris, 3-6 June 1998, 367-376. 
[29] AFED (Arab Forum for Environment and Development) (2009) Impact of Climate Change on Arab Countries. http://www.afedonline.org/en/

[30] Yildiz, D. (2015) New International Security Paradigm Related to Water and Environmental Security. World Scientific News, 19, 133-147. http://www.worldscientificnews.com/article-in-press/2015-2/19-24-2015/

[31] Medany, M. (2008) Impact of Climate Change on Arab Countries. In: Tolba, M. and Saab, N., Eds., Arab Environment Future Challenges, Arab Forum for Environment Development, Chapter 9. http://www.afedonline.org/afedreport/full\%20english\%20report.pdf

[32] Oweis, T. and Hachum, A. (2004) Water Harvesting and Supplemental Irrigation for Improved Water Productivity of Dry Farming Systems in West Asia and North Africa. New Directions for a Diverse Planet. Proceedings of the 4th International Crop Science Congress, Brisbane, 26 September-1 October 2004. http://www.cropscience.org.au

[33] Al-Ansari, N.A., Abdellatif, M., Al-Khateeb, M. and Knutsson, S. (2014) Desertification and Future Rainfall Trends North Iraq. 8 th Edition of the International Scientific Congress of GIS and Geospace Applications Geotunis, Tunis, 2-4 April 2014.

[34] Al-Ansari, N.A., Abdellatif, M., Zakaria, S., Mustafa, Y. and Knutsson, S. (2014) Future Prospects for Macro Rainwater Harvesting (RWH) Technique in North East Iraq. Journal of Water Resource and Protection, 6, 403-420. https://doi.org/10.4236/jwarp.2014.65041

[35] Al-Ansari, N.A., Abdellatif, M., Ezeelden, M., Ali, S. and Knutsson, S. (2014) Climate Change and Future Long Term Trends of Rainfall at North-Eastern Part of Iraq. Journal of Civil Engineering and Architecture, 8, 790-805.

[36] Osman, Y., Abdellatif, M., Al-Ansari, N.A., Knutsson, S. and Aljawad, S.B. (2017) Climate Change and Future Precipitation in Arid Environment of Middle East: Case Study of Iraq. Journal of Environmental Hydrology, 25, 1-18.

[37] Osman, Y., Al-Ansari, N.A. and Abdellatif, M. (2017) Climate Change Model as a Decision Support Tool for Water Resources Management: A Case Study of Greater Zab River. Journal of Water and Climate Change, 8, 1-14.

[38] UN (2010) Water Resources Management White Paper, United Nations Assistance Mission for Iraq. United Nations Country Team in Iraq, $20 \mathrm{p}$.

[39] Janabi, H. (2010) Water Security in Iraq. Iraqi's Ambassador to the UN Agencies in Rome, FAO Meeting.

[40] Al-Ansari, N.A. (2013) Management of Water Resources in Iraq: Perspectives and Prognoses. Journal of Engineering, 5, 667-684. https://doi.org/10.4236/eng.2013.58080

[41] UN (2013) United Nations World Water Development Report 4. Volume 1: Managing Water under Uncertainty and Risk. https://sustainabledevelopment.un.org/content/documents/404water.pdf

[42] SIWI (Stockholm International Water Institute) (2009) Water Resources in the Middle East. Background Report to Seminar on Water and Energy Linkages in the Middle East, 9 p.

[43] IAU (Inter-Agency Information and Analysis Unit) (2011) Water in Iraq Factsheet. http://www.iauiraq.org/documents/1319/Water\%20Fact\%20Sheet\%20March\%2020 11.pdf

[44] Investors Iraq (2009) Water Crisis in Iraq: The Growing Danger of Desertification. http://www.investorsiraq.com/showthread.php?132306-Water-Crisis-in-Iraq-The-G 
$\underline{\text { rowing-Danger-of-Desertification\&s=bac86eb806dc1177231fc10190b17dbf }}$

[45] IMMPW Iraqi Ministry of Municipalities and Public Work (2011) Water Demand and Supply in Iraq: Vision, Approach and Efforts, GD for Water.

http://www.mmpw.gov.iq/

[46] MICS (Multiple Indicator Cluster Survey) (2007) IRAQ: Monitoring the Situation of Children and Women. Final Report. http://www.childinfo.org/files/MICS3_Iraq_FinalReport_2006_eng.pdf

[47] UNICEF (2003) Iraq Watching Briefs. Water and Environmental Sanitation, 64 p. http://www.unicef.org/evaldatabase/files/Iraq_2003_Watching_Briefs.pdf

[48] A Climate for Change (2012) Water Supply and Sanitation in Iraq. http://www.aclimateforchange.org/profiles/blogs/water-supply-and-sanitation-in-ir aq

[49] Relief Web (2003) Water and Sanitation in Iraq. http://reliefweb.int/report/iraq/water-and-sanitation-iraq

[50] The Encyclopedia of Earth (2008) Water Profile of Iraq. http://www.eoearth.org/article/Water_profile_of_Iraq

[51] Raphaeli, N. (2009) Water Crisis in Iraq: The Growing Danger of Desertification. Investors Iraq, July 23 2009, No. 537.

http://www.investorsiraq.com/showthread.php?132306-Water-Crisis-in-Iraq-The-G rowing-Danger-of-Desertification

[52] Aydin, M. and Ereker, F. (2009) Water Scarcity and Political Wrangling: Security in the Euphrates and Tigris Basin. In: Brauch, et al., Eds., Facing Global Environmental Change: Environmental, Human, Energy, Food, Health and Water Security Concepts, Springer, Berlin, 603-613. https://doi.org/10.1007/978-3-540-68488-6_44

[53] Smakhtin, V., Revenga, C. and Döll, P. (2004) Taking into Account Environmental Water Requirements in Global-Scale Water Resources Assessments. https://core.ac.uk/download/pdf/6405183.pdf

[54] Reig, P., Maddocks, A. and Gassert, F. (2013) World's 36 Most Water-Stressed Countries. World Resources Institute.

http://www.wri.org/blog/2013/12/world\%E2\%80\%99s-36-most-water-stressed-coun $\underline{\text { tries }}$

[55] Berardinucci, J. (2010) The Impact of Power on Water Rights: A Study of the Jordan and Tigris-Euphrates Basins. Bachelor of Art Report, School of International Service, American University, Washington DC.

http://aladinrc.wrlc.org/bitstream/handle/1961/9171/Berardinucci,\%20Jessica\%20\%20Spring\%20'10\%20(P).pdf?sequence $=1$

[56] Ameed, M., Ahmadalipour, A. and Moradkhani, H. (2018) Apprehensive Drought Characteristics over Iraq: Results of a Multidecadal Spatiotemporal Assessment. Geosciences, 8, 1-16.

[57] Parolari, A.J., Li, D., Bou-Zeid, E., Katul, G.G. and Assouline, S. (2017) Climate, Not Conflict, Explains Extreme Middle East Dust Storm. Environmental Research Web. http://environmentalresearchweb.org/cws/article/news/67522

[58] Naranjo, L. (2016) Crisis in the Crescent. NASA Earth Data. https://earthdata.nasa.gov/user-resources/sensing-our-planet/crisis-in-the-crescent

[59] Sissakian, V., Al-Ansari, N.A. and Knutsson, S. (2013) Sand and Dust Storm Events in Iraq. Journal of Natural Sciences, 5, 1084-1094. https://doi.org/10.4236/ns.2013.510133 